\title{
Neofusicoccum spp. Associated with Stem Canker and Dieback of Blueberry in Chile
}

J. G. Espinoza and E. X. Briceño, Facultad de Agronomía e Ingeniería Forestal, Pontificia Universidad Católica de Chile, Casilla 306-22, Santiago, Chile; E. R. Chávez, Laboratorio de Micología, Servicio Agrícola y Ganadero, Lo Aguirre, Ministerio de Agricultura, Chile; J. R. Úrbez-Torres, Department of Plant Pathology, University of California, Davis 95616; and B. A. Latorre, Facultad de Agronomía e Ingeniería Forestal, Pontificia Universidad Católica de Chile, Casilla 306-22, Santiago, Chile

\begin{abstract}
Espinoza, J. G., Briceño, E. X., Chávez, E. R., Úrbez-Torres, J. R., and Latorre, B. A. 2009. Neofusicoccum spp. associated with stem canker and dieback of blueberry in Chile. Plant Dis. 93:1187-1194.

Blueberry (Vaccinium spp.) plantings have significantly increased in Chile during the last decade and, currently, over 10,700 ha are cultivated throughout the country. Among other diseases, stem canker and dieback has been frequently observed in commercial plantations with incidences between 15 and $45 \%$. The aim of this study was to identify and characterize Neofusicoccum spp. causing stem canker and dieback of blueberry in Chile. Three species, N. arbuti, N. australe, and $N$. parvum, were identified based on colony and conidia morphology, and nucleotide sequence analysis of the internal transcribed spacer (ITS) region (ITS1-5.8S-ITS2). These Neofusicoccum spp. were found alone or coexisting with Pestalotiopsis spp., Truncatella spp., or Phomopsis spp. Koch's postulates showed all Neofusicoccum spp. isolated from infected plants to be pathogenic when inoculated on blueberry fruit and twigs using both mycelia and conidia suspension. All blueberry cultivars tested, including, Brigitta, Bluecrop, Brightwell, Duke, Elliott, Misty, and O'Neal, were susceptible to Neofusicoccum spp. infection. Pathogenicity tests showed N. parvum to be the most virulent species and Elliott to be the most susceptible cultivar. This report represents the first description of $N$. arbuti, $N$. australe, and $N$. parvum as canker-causing agents on blueberry in Chile.
\end{abstract}

Blueberry (Vaccinium spp.), with over 10,700 ha planted and 30,000 $\mathrm{t}$ of production in 2008 , has become an economically important crop during the last decade in Chile. Blueberry production is mainly exported to the United States and Europe. Blueberry commercial plantations in Chile extend throughout a north-south axis of approximately $1,400 \mathrm{~km}$ in length under very different soil and environmental conditions $(3,27)$.

Several viral, bacterial, and fungal diseases have been described on blueberry worldwide $(6,14)$. Among these, stem canker and dieback of blueberry is a primary factor limiting both longevity and production. To date, more than 250 Botryosphaeriaceae spp., including species of $\mathrm{NeO}$ fusicoccum, are known to occur worldwide and have been described as plant pathogens, saprophytes, or endophytes of both cultivated and native plants $(5,13,37)$.

Botryosphaeriaceae spp. have been associated with canker and dieback symptoms in a broad range of different peren-

Corresponding author: B. A. Latorre
E-mail: blatorre@uc.cl

Accepted for publication 13 July 2009.

doi:10.1094/PDIS-93-11-1187

(c) 2009 The American Phytopathological Society nial fruit crops worldwide, and their importance as canker-causing and fruit rot agents has been extensively recognized (2,7,18,19,22-24,28-30,34,37,39,43,47). Botryosphaeria corticis and $B$. dothidea have been reported to cause twig and stem dieback, leaf spots, and fruit rots on blueberry and have been responsible for devastating disease outbreaks in the United States (23). B. dothidea and B. ribis were reported in blueberry plantations located in the VII and X regions in southern Chile in $2003(11,16)$. Blueberry fruit are currently grown in a wide geographic zone of Chile under very different agricultural and environmental conditions that may favor the development of new diseases. Canker and stem dieback has been commonly observed during the past few years in Chile and disease incidence varies between 15 and $45 \%$. However, no comprehensive effort to identify the canker-causing agents occurring in Chile has been reported. The purpose of this study was to identify and characterize the Neofusicoccum spp. associated with canker and stem dieback of blueberry in Chile by means of morphological features, DNA analyses, and pathogenicity studies.

\section{MATERIALS AND METHODS}

Sampling locations and fungal isolation. Symptomatic stems (1 and 2 years old) were collected from eight commercial blueberry plantations, including northern high bush (Vaccinium corymbosum) (cvs. Aurora, Bluegold, Brigitta, Duke, Elliot, and Liberty) and southern high bush ( $V$. corymbosum $\times V$. darrowi) (cv. Misty) blueberry cultivars. Plantations were located in the Metropolitan Region (33 ${ }^{\circ} 16^{\prime}$ $\mathrm{S})$, VI Region $\left(34^{\circ} 00^{\prime} \mathrm{S}\right)$, and $\mathrm{X}$ Region $\left(40^{\circ} 45^{\prime} \mathrm{S}\right)$ of Chile (Table 1). Samples were surface disinfected in $0.5 \% \mathrm{NaOCl}$ for $2 \mathrm{~min}$ in the laboratory. Small fragments $\left(5 \mathrm{~mm}^{2}\right)$ of necrotic tissue were cut from the margins of the stem lesions after peeling of the bark and plated on potato dextrose agar (PDA) acidified with 96\% lactic acid (APDA) at $0.5 \mathrm{ml} /$ liter. Cultures were incubated in the dark at $20^{\circ} \mathrm{C}$ until colonies were observed. Pure cultures were obtained by hyphal tips from the margin of the suspected Neofusicoccum colonies, which were subcultured on fresh APDA and maintained at $20^{\circ} \mathrm{C}$.

Characterization and identification of fungal isolates. Identification of the fungal colonies was first based on colony and conidia morphology. In order to enhance conidia formation, 4-day-old mycelium plugs from the different fungal isolates were cultivated on autoclaved Pinus radiata needles aseptically placed on $2 \%$ water agar. Cultures were incubated at $25^{\circ} \mathrm{C}$ for 7 to 10 days under continuous UV light. After sporulation, length, width, color, and the presence or absence of septa of 50 conidia were determined for each Neofusicoccum isolate using an optical microscope (Olympus Cx31 provided with an Evolution LC camera) (Table 2). The results were compared with previous descriptions $(10,17,30,44)$.

Morphological characterization was corroborated by molecular analysis. Genomic DNA from 1-week-old cultures from eight Neofusicoccum isolates was extracted using the protocol previously described (8). Internal transcribed spacer (ITS) primers ITS1 and ITS4 were used to amplify the ITS1-5.8S-ITS2 region (49). The polymerase chain reaction (PCR) was performed in a thermocycler (MiniCycler; MJ Research Inc., Watertown, MA) using 50 $\mu \mathrm{l}$ of reaction mixture composed of DNAsa-free water $(17.0 \mu \mathrm{l}) ; 1 \times \quad$ PCR buffer solution (Tris $\mathrm{HCl}$ ) containing 50 $\mathrm{mM} \mathrm{MgCl}_{2}, 0.25 \mathrm{mM}$ dNTPs, bovine se- 
rum albumen at $1 \mathrm{mg} \mathrm{ml}^{-1}, 0.2 \mu \mathrm{M}$ primer ITS4, $0.2 \mu \mathrm{M}$ primer ITS1, Taq DNA po-

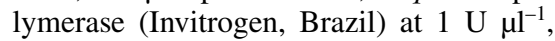
and $1 \mu \mathrm{l}$ of genomic DNA. After an initial denaturation for $2 \mathrm{~min}$ at $94^{\circ} \mathrm{C}, 40 \mathrm{PCR}$ cycles were performed at $94^{\circ} \mathrm{C}$ for $30 \mathrm{~s}$, followed by annealing at $55^{\circ} \mathrm{C}$ for $45 \mathrm{~s}$ and elongation at $72^{\circ} \mathrm{C}$ for $90 \mathrm{~s}$, with a final elongation step at $72^{\circ} \mathrm{C}$ for $5 \mathrm{~min}$ $(32,37,38)$. PCR products were separated by electrophoresis (Model 250 EX Life Technologies, GIBCO BRL Electrophoresis Power Supply, and HU10W SCIEPLAS, England) ( $80 \mathrm{~V}$ for $50 \mathrm{~min}$ ) in a $1.5 \%$ agarose gel in $10 \times$ Tris-acetateEDTA UltraPure buffer solution $(0.4 \mathrm{~m}$ Tris, $0.05 \mathrm{M}$ acetic acid, and $0.01 \mathrm{M}$ EDTA, pH 7.85). For each electrophoresis, a 100-bp ladder marker (Invitrogen, Carlsbad, CA) (0.5 $\mu$ l of marker and load buffer solution) was used. The profiles obtained were visualized under UV light (UV Tran- silluminator UVP, Upland, CA) after staining the gel with $1 \%$ ethidium bromide for 10 to $15 \mathrm{~min}$. PCR products were separated and purified using AxigenPrep PCR (Axigen), and DNA concentrations were estimated using a Nanodrop (ND 1000UV/Vis spectrophotometer; Nanodrops Technologies, Inc.). Each PCR product was sequenced in both directions using Macrogen (Macrogen, Korea). The results were manually aligned using an ITS ribosomal DNA (rDNA) gene sequence according to Chromas (Technelysium Pty Ltd., Australia).

Sequences of Neofusicoccum spp. from Chile were compared with extype species from previous studies available in GenBank (25; Table 3). The alignment was corrected by visual inspection and any ambiguously aligned characters were deleted. Phylogenetic analysis was run for the ITS dataset using PAUP (version 4.0b10; Sinauer Associates, Inc., Publishers, Sunderland, MA). B. dothidea was used as outgroup. Maximum parsimony was performed using the heuristic search option (branch swapping NNI) and 1,000 random addition sequences replicates. Bootstrap values were evaluated using 1,000 replicates to test branch strength. Tree length, consistency index (CI), retention index (RI), rescaled consistency index (RC), and homoplasy index (HI) were also recorded. Resulting trees were printed in PAUP (version 4.0b10). ITS Neofusicoccum sequences from Chile were deposited into GenBank (25). Neofusicoccum spp. isolated from blueberry in Chile were deposited in CABI Genetic Resource Collection (Surrey, UK).

Effect of temperature on mycelial growth. In order to determine optimum growth temperature for the different $\mathrm{NeO}$ fusicoccum isolates, four replicates of a 5 -

Table 1. Host and origin of Neofusicoccum isolates obtained in this study from commercial blueberry (Vaccinium spp.) plantations in Chile during 2005 and 2006

\begin{tabular}{|c|c|c|c|c|c|}
\hline \multirow[b]{2}{*}{ Isolates $^{x}$} & \multicolumn{2}{|l|}{ Origin } & \multirow[b]{2}{*}{ Host } & \multirow[b]{2}{*}{ Cultivar } & \multirow[b]{2}{*}{ IMI no. ${ }^{y}$} \\
\hline & Locality & South latitude & & & \\
\hline \multicolumn{6}{|l|}{ N. arbuti } \\
\hline $\mathrm{B} 03-07^{\mathrm{z}}$ & Río Negro, Osorno, X Region & $40^{\circ} 45^{\prime}$ & Vaccinium corymbosum & Aurora & 395833 \\
\hline B04-07 & Río Negro, Osorno, X Region & $40^{\circ} 45^{\prime}$ & V. corymbosum & Aurora & $\ldots$ \\
\hline B05-07 & Río Negro, Osorno, X Region & $40^{\circ} 45^{\prime}$ & V. corymbosum & Bluegold & $\ldots$ \\
\hline B06-07 & Río Negro, Osorno, X Region & $40^{\circ} 45^{\prime}$ & V. corymbosum & Brigitta & $\cdots$ \\
\hline $\mathrm{B} 09-07^{\mathrm{z}}$ & Río Negro, Osorno, X Region & $40^{\circ} 45^{\prime}$ & V. corymbosum & Brigitta & 395834 \\
\hline $\mathrm{B} 62-07^{\mathrm{z}}$ & Río Negro, Osorno, X Region & $40^{\circ} 45^{\prime}$ & V. corymbosum & Elliott & $\ldots$ \\
\hline \multicolumn{6}{|l|}{ N. australe } \\
\hline $\mathrm{B} 1-05^{\mathrm{z}}$ & Rapel, VI Region & $34^{\circ} 00^{\prime}$ & V. corymbosum & Duke & $\ldots$ \\
\hline \multicolumn{6}{|l|}{ N. parvum } \\
\hline B1-06 & Lampa, Santiago, RM & $33^{\circ} 16^{\prime}$ & $V$. corymbosum $\times V$. darrowi & Mysti & $\ldots$ \\
\hline B02-07 & Nancagua, VI Region & $34^{\circ} 40^{\prime}$ & V. corymbosum & Brigitta & 395832 \\
\hline $\mathrm{B} 4.2-06^{\mathrm{z}}$ & Rapel, VI Region & $34^{\circ} 00^{\prime}$ & V. corymbosum & Duke & 395831 \\
\hline \multicolumn{6}{|c|}{ Neofusicoccum sp. } \\
\hline B01-07 & Río Negro, Osorno, X Region & $40^{\circ} 45^{\prime}$ & V. corymbosum & Liberty & \\
\hline B08-07 & Río Negro, Osorno, X Region & $40^{\circ} 45^{\prime}$ & V. corymbosum & Brigitta & 396598 \\
\hline B2.1-07 & Río Negro, Osorno, X Region & $40^{\circ} 45^{\prime}$ & V. corymbosum & Liberty & $\ldots$ \\
\hline
\end{tabular}

${ }^{\mathrm{x}}$ Neofusicoccum spp. from blueberry in Chile were determined based on colony and conidial morphology and DNA analyses.

${ }^{y}$ Isolates deposited at the International Mycological Institute (IMI) CABI Genetic Resource Collection, Surrey, UK.

${ }^{\mathrm{z}}$ Isolates used for phylogenetic analysis.

Table 2. Conidial characteristics of Neofusicoccum spp. isolated from blueberry (Vaccinium spp.) in Chile

\begin{tabular}{llll}
\hline Isolates & \multicolumn{1}{c}{ Size $(\boldsymbol{\mu m})^{\mathbf{y}}$} & Mean $\pm \mathbf{S D}(\boldsymbol{\mu m})^{\mathbf{z}}$ & Length:width ratio \pm SD $^{\mathbf{z}}$ \\
\hline Neofusicoccum arbuti & $(19.1-) 22.9-28.7 \times(5.4-) 7.1-8.8$ & & \\
B03-07 & $(16.3-) 19.5-27.6 \times(6.3-) 8.4-10.6$ & $23.6 \pm 2.0 \times 7.2 \pm 0.7$ & $3.3 \pm 0.4$ \\
B04-07 & $(23.3-) 25.3-29.3 \times(6.6-) 7.7-9.3$ & $25.6 \pm 1.7 \times 7.6 \pm 0.7$ & $3.5 \pm 0.4$ \\
B05-07 & $(21.9-) 26.7-30.5 \times(6.3-) 6.5-9.5$ & $26.5 \pm 1.7 \times 7.6 \pm 0.7$ & $3.3 \pm 0.3$ \\
B06-07 & $(20.4-) 25.4-31 \times(4.8-) 6.9-9.3$ & $25.5 \pm 2.1 \times 7.1 \pm 0.9$ & $3.5 \pm 0.4$ \\
B09-07 & $(19.1-) 23.7-26.9 \times(6.2-) 7.5-8.03$ & $24.3 \pm 1.5 \times 7.0 \pm 0.5$ & $3.6 \pm 0.6$ \\
B62-07 & $(17.1-) 20.1-23.6 \times(7.5-) 9.5-10$ & $20.4 \pm 1.4 \times 8.8 \pm 0.7$ & $3.5 \pm 0.4$ \\
N. australe & & & $2.1 \pm 0.3$ \\
B1-05 & $(16.1-) 19.9-21.9 \times(7.4-) 9.3-10.9$ & $19.3 \pm 1.4 \times 9.4 \pm 0.8$ & $2.3 \pm 0.3$ \\
N. parvum & $(19.1-) 23.3-24.8 \times(6.3-) 7.8-10.8$ & $21.7 \pm 1.3 \times 8.0 \pm 0.9$ & $2.8 \pm 0.4$ \\
B1-06 & $(12.2-) 22.2 \times(5.2-) 8.4-9.7$ & $17.5 \pm 2.2 \times 8.1 \pm 0.7$ & $2.2 \pm 0.3$ \\
B02-07 & $(19.3-) 25.8-28.7 \times(5-) 7.5-8.8$ & $24.9 \pm 2.2 \times 7.4 \pm 0.8$ & $3.4 \pm 0.6$ \\
B4.2-06 & $(20.9-) 26.3-28 \times(6.5-) 7.4-9.2$ & $25.0 \pm 1.5 \times 7.8 \pm 0.9$ & $3.2 \pm 0.3$ \\
Neofusicoccum sp. & $(20.7-) 23.3-30.6 \times(5-) 7.1-8.1$ & $24.7 \pm 1.9 \times 6.6 \pm 0.7$ & $3.8 \pm 0.5$ \\
B01-07 & B08-07 & & \\
B2.1-07 & &
\end{tabular}

${ }^{y}$ Minimum size shown between parentheses followed by mode and maximum size in length and width of 50 conidia were recorded for each Neofusicoccum isolate from blueberry in Chile.

${ }^{\mathrm{z}} \mathrm{SD}=$ standard deviation. 
mm-diameter mycelial plug from seven isolates of the different Neofusicoccum spp. were cultured on APDA and incubated separately from 0 to $40^{\circ} \mathrm{C}\left( \pm 0.5^{\circ} \mathrm{C}\right)$ at $5^{\circ} \mathrm{C}$ intervals. The effect of the temperature on colony growth was determined by measuring the radial growth of the mycelia after 4 days of incubation in the dark. This experiment was repeated twice.

Pathogenicity tests. Pathogenicity of Neofusicoccum arbuti, N. australe, and N. parvum (Table 4) was first studied in mature apple cv. Granny Smith and kiwifruit cv. Hayward. A second pathogenicity test was conducted on lignified 2-year-old detached stems from blueberry plant cvs. Brigitta and O'Neal. Fruit and detached stems were inoculated using 5-mmdiameter mycelial plugs from 7-day-old cultures on APDA. Fruit surfaces were disinfected using $0.5 \% \mathrm{NaOCl}$ and $0.05 \%$ ethanol for $60 \mathrm{~s}$ and injured with the aid of a cork borer before inoculation. Concurrently, the same fruit were also inoculated on the uninjured skin, opposite to the wounded side. An equal number of fruit equally treated but using sterile agar plugs were left as control. To avoid rapid dehydration, the inoculation site was covered with Parafilm (Pechiney Plastic Packaging, Menasha, WI). Fruit were incubated at $20^{\circ} \mathrm{C}$ in humid chambers with $100 \%$ relative humidity $(\mathrm{RH})$ as determined with an $\mathrm{RH}$ microsensor (StowAway RH). The size of necrotic lesions was determined after 7 to 10 days of incubation.
The pathogenicity of $N$. parvum B01-06, B4.2-06, and B02-07, which were the most aggressive isolates in apple and kiwifruit fruit, was repeated on wounded detached blueberry stems (cv. O'Neal) using separately mycelial plugs and $15 \mu \mathrm{l}$ of a conidial suspension $\left(10^{6}\right.$ conidia $\left.\mathrm{ml}^{-1}\right)$. Inoculated stems were incubated for 25 days in humid chamber at $20^{\circ} \mathrm{C}$.

A pathogenicity test was performed on 2-year-old potted blueberry cvs. Brigitta and O'Neal. Stems were surface disinfected with $0.5 \% \mathrm{NaOCl}$ for $60 \mathrm{~s}$ before making a tangential cut (5 $\mathrm{mm}$ in length) on the bark. A 5-mm-diameter mycelial plug was taken from 5-day-old cultures on APDA and inserted underneath the bark. To avoid rapid dehydration, the inoculation sites were covered with Parafilm for 3 days. Plants were incubated under semishaded conditions. The length of the necrotic lesion was determined 25 days after inoculation.

To compare the effect of mycelial and conidial inoculations, detached stems of blueberry cv. O'Neal were inoculated with $N$. parvum, which was shown to be the most virulent isolate in the previous experiment. For this purpose, 2-year-old stems $(20 \mathrm{~cm}$ in length and with a similar diameter) were surface disinfected, injured as indicated above, and then inoculated with either a 5 -mm mycelium plug or $15 \mu \mathrm{l}$ of $10^{6}$ conidia $\mathrm{ml}^{-1}$ obtained from pycnidia that were crushed in sterile water. All stems were vertically distributed in humid

Table 3. Neofusicoccum isolates from GenBank used for phylogenetic analyses

\begin{tabular}{lcll}
\hline Species & GenBank accession no. & Origin & \multicolumn{1}{c}{ Host } \\
\hline Neofusicoccum arbuti & UW01z & United States & Arbutus menziesii \\
N. australe & CMW $6837^{\mathrm{z}}$ & Australia & Acacia sp. \\
N. corticosae & CPC $12926^{\mathrm{z}}$ & Australia & Eucalyptus carticosa \\
N. mediterraneum & CPC $13137^{\mathrm{z}}$ & Greece & Eucalyptus sp. \\
N. parvum & $96-29^{\mathrm{z}}$ & New Zealand & Malus sp. \\
N. vitifusiforme & CAP 227 & Italy & Olea europaea \\
\hline
\end{tabular}

${ }^{\mathrm{z}}$ Extype isolates.

Table 4. Pathogenicity of Neofusicoccum spp. obtained from blueberry in fruit of Granny Smith apple, Hayward kiwifruit, and blueberry stems ${ }^{\mathrm{z}}$

\begin{tabular}{|c|c|c|c|c|c|c|c|c|c|c|c|}
\hline \multirow[b]{2}{*}{ Species } & \multicolumn{2}{|c|}{ Apple fruit (mm) } & \multicolumn{2}{|c|}{ Kiwifruit fruit (mm) } & \multicolumn{2}{|c|}{ Blueberry stems (mm) } & \multirow[b]{2}{*}{ df } & \multicolumn{2}{|c|}{ Apple } & \multicolumn{2}{|c|}{ Kiwifruit } \\
\hline & Mycelia & Conidia & Mycelia & Conidia & Brigitta & O'Neal & & $\boldsymbol{F}$ & $\boldsymbol{P}$ & $\boldsymbol{F}$ & $\boldsymbol{P}$ \\
\hline \multicolumn{12}{|c|}{ Neofusicoccum arbuti } \\
\hline B03-07 & $34.3 \mathrm{~b}$ & nd & 19.0 bcde & nd & $13.7 \mathrm{~b}$ & $12.5 \mathrm{~b}$ & $\ldots$ & $\ldots$ & $\ldots$ & $\ldots$ & $\ldots$ \\
\hline B09-07 & $34.7 \mathrm{~b}$ & nd & $16.5 \mathrm{bc}$ & nd & $14.0 \mathrm{~b}$ & $11.3 \mathrm{~b}$ & $\ldots$ & $\ldots$ & $\ldots$ & $\ldots$ & $\ldots$ \\
\hline B62-07 & $30.0 \mathrm{~b}$ & nd & $14.00 \mathrm{~b}$ & nd & $13.3 \mathrm{~b}$ & $11.3 \mathrm{~b}$ & $\ldots$ & $\ldots$ & $\ldots$ & $\ldots$ & $\ldots$ \\
\hline \multicolumn{12}{|l|}{ N. australe } \\
\hline B1-05 & $28.3 \mathrm{~b}$ & nd & $23.5 \mathrm{de}$ & nd & $26.0 \mathrm{bc}$ & $17.5 \mathrm{~b}$ & $\ldots$ & $\ldots$ & $\ldots$ & $\ldots$ & $\ldots$ \\
\hline \multicolumn{12}{|l|}{ N. parvum } \\
\hline B1-06 & $43.5 \mathrm{bc}$ & $43.2 \mathrm{~b}$ & $23.0 \mathrm{de}$ & $18.7 \mathrm{~b}$ & $44.0 \mathrm{~cd}$ & $63.9 \mathrm{c}$ & $\ldots$ & $\ldots$ & $\ldots$ & $\ldots$ & $\ldots$ \\
\hline B4.2-06 & $55.7 \mathrm{c}$ & $50.5 \mathrm{~b}$ & 20.5 cde & $22.0 \mathrm{~b}$ & nd & nd & $\ldots$ & $\ldots$ & $\ldots$ & $\ldots$ & $\ldots$ \\
\hline B02-07 & $33.7 \mathrm{~b}$ & $41.0 \mathrm{~b}$ & $24.50 \mathrm{e}$ & $20.0 \mathrm{~b}$ & $95.5 \mathrm{~d}$ & $70.7 \mathrm{c}$ & $\ldots$ & $\ldots$ & $\ldots$ & $\ldots$ & $\ldots$ \\
\hline \multicolumn{12}{|l|}{ Control } \\
\hline Noninoculated & $0.0 \mathrm{a}$ & $0.0 \mathrm{a}$ & $0.0 \mathrm{a}$ & $0 \mathrm{a}$ & $0 \mathrm{a}$ & $0 \mathrm{a}$ & $\ldots$ & $\ldots$ & $\ldots$ & $\ldots$ & $\ldots$ \\
\hline \multicolumn{12}{|c|}{ Analysis of variance } \\
\hline Isolate (I) & $\ldots$ & $\ldots$ & $\ldots$ & $\ldots$ & $\ldots$ & $\ldots$ & 6 & 5.05 & 0.006 & 10.44 & $<0.001$ \\
\hline Methods (M) & $\ldots$ & $\ldots$ & $\ldots$ & $\ldots$ & $\ldots$ & $\ldots$ & 1 & 443.13 & $<0.001$ & $1,841.02$ & $<0.001$ \\
\hline $\mathrm{I} \times \mathrm{M}$ & $\ldots$ & $\ldots$ & $\ldots$ & $\ldots$ & $\ldots$ & $\ldots$ & 6 & 4.65 & 0.001 & 10.54 & $<0.001$ \\
\hline
\end{tabular}

${ }^{\mathrm{z}}$ Fruit and stems were inoculated with a 5-mm mycelial plug. Fruit were also inoculated with $15 \mu \mathrm{l}$ of a $10^{6}$ conidia/ml conidial suspension. Results of fruit inoculations were obtained after 7 to 10 days and stem inoculations were obtained after 25 days of incubation. Means followed by different letters in each column are significantly different according to the Tukey's test $(P=0.05)$; nd, not determined. 
iprodione (Rovral 4 F; Bayer Crop Science, Santiago, Chile), fludioxonil (Scholar 230 SC; Syngenta Crop Protection), and pyraclostrobin (Comet $250 \mathrm{SL}$; BASF) was studied in vitro.

Small fragments (5 $\mathrm{mm}$ in length) of mycelium were placed in quadruplicate 90-mm-diameter petri plates containing APDA emended with the respective fungicides at $1 \mu \mathrm{m} \operatorname{liter}^{-1}$. Each fungicide was suspended in sterile distilled water and added to autoclaved agar media after cooling the media to approximately $60^{\circ} \mathrm{C}$. All cultures were incubated at $25^{\circ} \mathrm{C}$ for $48 \mathrm{~h}$ before determining the radial growth of the mycelium.

The median effective concentration $\left(\mathrm{EC}_{50}\right)$ of fludioxonil and iprodione, the most effective fungicides in the previous experiment, was determined. Each isolate was seeded in quadruplicate on APDA containing the respective fungicide at 0 , $0.025,0.05,0.1,0.5,1.0,1.5$, and $2.0 \mu \mathrm{m}$ liter $^{-1}$. All cultures were incubated at $25^{\circ} \mathrm{C}$ for $48 \mathrm{~h}$ before determining the radial growth of the mycelium. Results are expressed as the control efficiency $(E)$ according to the following equation: $E=(A-$ $B) / A) \times 100$, where $A$ is the diameter of the fungus colony in control plates and $B$ is the colony diameter obtained in APDA plates emended with the respective fungicide.

Design and statistical analysis. The effect of temperature on mycelia radial growth and the study of mycelial growth rate, obtained among Neofusicoccum spp. in $48 \mathrm{~h}$ at $25^{\circ} \mathrm{C}$, were completely randomized with four replicates, using a petri plate as an experimental unit. Pathogenicity tests performed in fruit and stems were completely randomized using a fruit or a twig as experimental units. Tests performed on apple and kiwifruit were completely randomized with $7 \times 2$ (isolates $\times$ inoculation method) factorial arrangement of treatments.

The relative susceptibility of blueberry cultivars to Botryosphaeriaceae spp. was studied according to complete block design with a $7 \times 3$ (seven cultivars $\times$ three isolations) factorial arrangement of treat- ments, with four replicates of one plant each.

Data were subjected to analysis of variance and means were separated according to Tukey's test using SAS (SAS Institute, Cary, NC).

The $\mathrm{EC}_{50}$ of iprodione and fludioxonil was estimated by linear regression analysis between $y=$ percent mycelial growth inhibition and $x=\log$ of the concentration of each fungicide. Prior the analysis, the $y$ values were transformed using the Probit scale (SAS PROBIT).

\section{RESULTS}

Field survey and fungal isolations. Diseased plants in commercial plantations were characterized by the presence of reddish-brown necrotic lesions that extended from the base of the stem to the crown during spring and summer. Symptoms were often observed only in one side of the plants. Bud necrosis, twig dieback, and eventual death of stems were also observed. Internal lesions were characterized by vascular discoloration of the xylem in diseased branches (Fig. 1).

Neofusicoccum spp. were isolated in 6 of 12 surveyed blueberry plantations (Metropolitan Region, Region VI, and Region $\mathrm{X}$; Table 1). In four of those six blueberry plantations, only Neofusicoccum spp. were isolated. In the other two plantations, Neofusicoccum spp. were co-isolated with

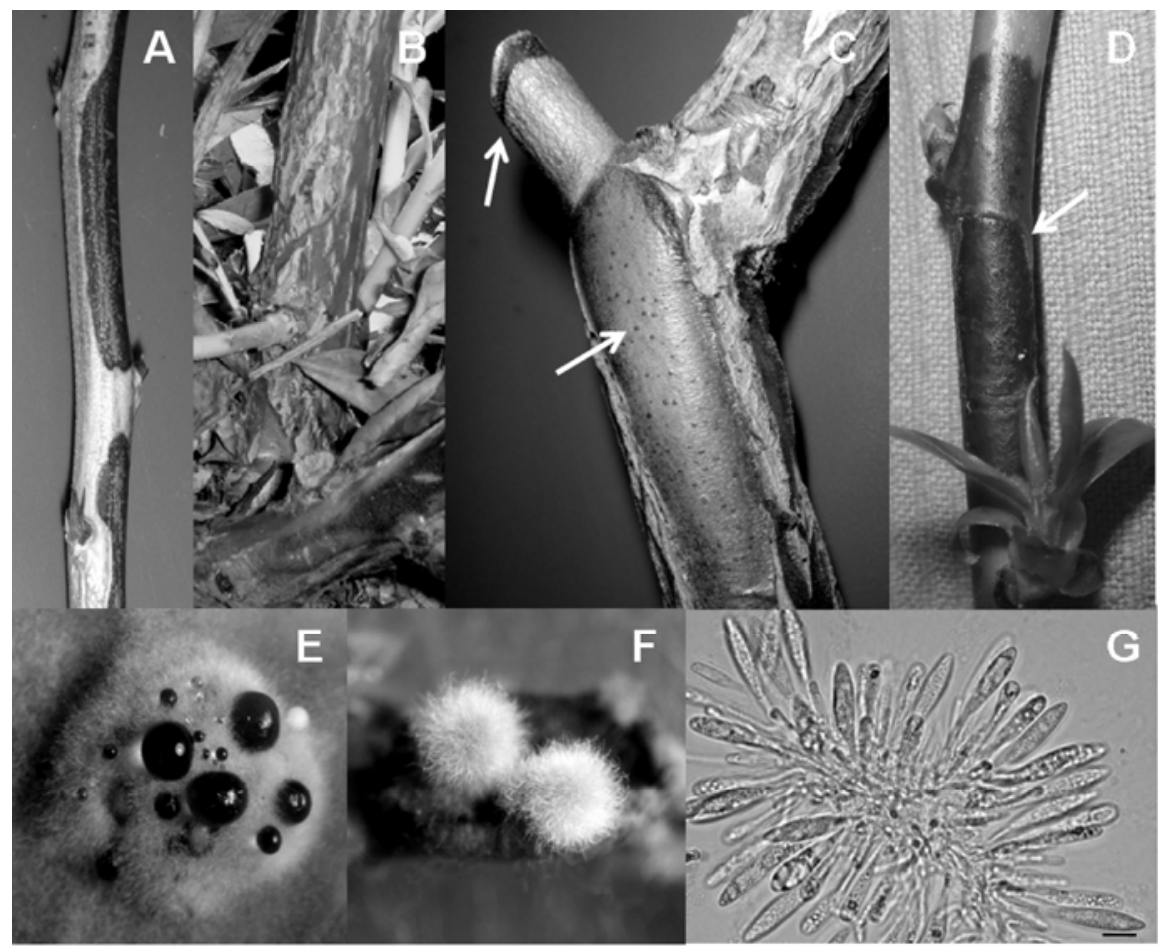

Fig. 1. Symptoms of canker and dieback of blueberry (Vaccinium spp.) caused by Botryosphaeriaceae spp. A-C, Symptoms observed in commercial blueberry plantations in Chile. A, Partially necrotic stem. B, Necrosis observed in the basal portion and crown of blueberry plants. C, Canker associated with pruning wound. Arrows show the pruning wound and pycnidia subcortical. D, Canker lesion obtained after stem inoculations. E, Pycnidia multiloculate on acidified potato dextrose agar medium. F, Single pycnidia on pine aciculae. G, Conidiophores and conidia of Neofusicoccum arbuti. Bar $=10 \mu \mathrm{m}$.

Table 5. Relative susceptibility of blueberry (Vaccinium spp.) after stem inoculations with mycelia of Neofusicoccum australe and N. parvum, and conidia of N. parvum $^{2}$

\begin{tabular}{|c|c|c|c|c|c|c|c|c|c|c|c|}
\hline \multirow[b]{2}{*}{ Isolate } & \multicolumn{8}{|c|}{ Length of lesion on blueberry cultivars (mm) } & \multirow[b]{2}{*}{ df } & \multirow[b]{2}{*}{$\boldsymbol{F}$} & \multirow[b]{2}{*}{$\boldsymbol{P}$} \\
\hline & Elliott & Brigitta & O’Neal & Brightwell & Duke & Bluecrop & Misty & Mean & & & \\
\hline \multicolumn{12}{|l|}{ Mycelia inoculation } \\
\hline N. australe B1-05 & 33.5 & 26.0 & 12.5 & 13.1 & 17.5 & 13.0 & 11.5 & $18.2 \mathrm{~b}$ & $\ldots$ & $\ldots$ & $\ldots$ \\
\hline N. parvum B1-06 & 120.7 & 44.0 & 63.9 & 47.5 & 35.7 & 31.2 & 26.0 & $52.7 \mathrm{a}$ & $\ldots$ & $\ldots$ & $\ldots$ \\
\hline N. parvum B4.2-06 & 24.0 & 21.0 & 11.2 & 12.0 & 10.5 & 18.2 & 17.7 & $16.4 \mathrm{~b}$ & $\ldots$ & $\ldots$ & $\ldots$ \\
\hline Mean & $59.4 \mathrm{~A}$ & $30.3 \mathrm{AB}$ & $29.2 \mathrm{AB}$ & $24.2 \mathrm{AB}$ & $21.2 \mathrm{~B}$ & $20.8 \mathrm{~B}$ & $18.4 \mathrm{~B}$ & $\ldots$ & $\ldots$ & $\ldots$ & $\ldots$ \\
\hline \multicolumn{12}{|l|}{ Analysis of variance } \\
\hline Cultivars (C) & $\ldots$ & $\ldots$ & $\ldots$ & $\ldots$ & $\ldots$ & $\ldots$ & $\ldots$ & $\ldots$ & 6 & 8.9 & $<0.001$ \\
\hline Neofusicoccum spp. (N) & $\ldots$ & $\ldots$ & $\ldots$ & $\ldots$ & $\ldots$ & $\ldots$ & $\ldots$ & $\ldots$ & 2 & 61.0 & $<0.001$ \\
\hline $\mathrm{C} \times \mathrm{N}$ & $\ldots$ & $\ldots$ & $\ldots$ & $\ldots$ & $\ldots$ & $\ldots$ & $\ldots$ & $\ldots$ & 12 & 1.9 & 0.057 \\
\hline \multicolumn{12}{|l|}{ Conidia inoculation } \\
\hline N. parvum (B1-06) & $37.5 \mathrm{~A}$ & $10.0 \mathrm{C}$ & 16.2 ABC & $31.2 \mathrm{AB}$ & $12.7 \mathrm{BC}$ & $9.7 \mathrm{C}$ & $11.7 \mathrm{BC}$ & $\ldots$ & $\ldots$ & $\ldots$ & $\ldots$ \\
\hline
\end{tabular}

${ }^{\mathrm{z}}$ Means followed in each line and column by different letters are significantly different according to Tukey's test $(P=0.05)$. Data were transformed to log $(x$

+1 ) before analysis, but untransformed data are also presented. 
species of Pestalotiopsis, Phomopsis, and Truncatella.

Characterization and identification. All isolates grew on APDA and developed white colonies that turned greenish or gray to black after 15 days. Of 13 isolates, 4 developed abundant aerial mycelia and 3 had scarce aerial growth. All isolates produced globular, black, solitary, or stromatic pycnidia on APDA or on $P$. radiata needles. Pycnidia were also observed on autoclaved blueberry stems as well as on the blueberry, apple, and kiwifruit fruit. Pycnidia produced hyaline conidia that were fusiform to ellipsoid and were borne on short hyaline conidiophores. Conidia were liberated in the form of whitish cirrus under humid conditions. Based on colony and conidia morphology, four different fungal groups were differentiated (Table 2).

The first fungal group formed white to olive-green colonies which developed moderate aerial growth. They produced small pycnidia dispersed on APDA after 20 days of incubation. Conidia were fusiform, hyaline, smooth, and guttulate in young cultures, with a truncated base, and occasionally dark and biseptate with age. Mean size was between $23.6 \pm 2.0 \times 7.2 \pm 0.7$ and $26.5 \pm 1.7 \times 7.6 \pm 0.7 \mu \mathrm{m}$, with a length:width $(\mathrm{L}: \mathrm{W})$ ratio between $3.2 \pm 0.4$ and $3.6 \pm 0.6$ (Table 2). This type of conidia was especially prominent on pycnidia developed on $P$. radiata needles. Stromatic black pycnidia with abundant aerial mycelia were produced on APDA (Fig. 2). All of these characters were in concordance with the description of $N$. arbuti (15).

The second fungal group formed slightly white to gray mycelia colonies and a characteristic yellow pigmentation was observed at the center of young colonies on APDA plates. Fluffy and cottony aerial mycelium developed in the center of the colonies and acquired a dark gray color with age. The underside of the colonies turned dark. Small black pycnidia covered with abundant mycelia developed after 15 days on $P$. radiata needles. Conidia were unicellular, fusiform, and hyaline, with a thin cell wall, with a mean size of $20.4 \pm$ $1.4 \times 8.8 \pm 0.7 \mu \mathrm{m}$ with $\mathrm{L}: \mathrm{W}$ ratio of $2.1 \pm$ 0.3 (Table 2). Microconidia were not observed (Fig. 2). All of these characters were in concordance with the description of $N$. australe $(10,20,37)$.

The third fungal group formed abundant aerial mycelia on APDA that were initially white to grayish but turned dark gray to olive green after 10 days at $25^{\circ} \mathrm{C}$. The mycelium exhibited rapid growth on APDA covering the petri dishes $(90 \mathrm{~mm})$ in $48 \mathrm{~h}$. Colonies stained the back of the culture media dark brown. Small, dark pycnidia covered with scarce mycelia were produced on $P$. radiata needles. Conidia from 15-day-old cultures were unicellular, hyaline, and ellipsoidal, with a truncated base, with mean size fluctuating between
$17.5 \pm 2.2 \times 8.1 \pm 0.7$ and $21.7 \pm 1.3 \times 8.0$ $\pm 0.9 \mu \mathrm{m}$, with a $\mathrm{L}: \mathrm{W}$ ratio of $2.2 \pm 0.3$ to $2.8 \pm 0.4$ (Table 2). Biseptate ellipsoidal conidia that were partially light brown appeared with a darker middle cell after 30 days (Fig. 2). All these characters were in concordance with the description of $N$.

The fourth fungal group formed olivegreen colonies with white margins, and moderate aerial mycelium was observed in the center of the colonies on APDA. The mycelium gradually turned dark green. The reverse of the cultures was darkly stained. Black pycnidia covered with scarce mycelia were produced on APDA. parvum (29-31).

The conidia were unicellular, hyaline, thinwalled, and fusiform to ellipsoid shaped with a truncated base, with mean size varying from $24.7 \pm 1.9 \times 6.6 \pm 0.7$ to $25.0 \pm$ $1.5 \times 7.8 \pm 0.9 \mu \mathrm{m}$, with a $\mathrm{L}: \mathrm{W}$ ratio between $3.2 \pm 0.3$ and $3.8 \pm 0.5$ (Table 2). Occasionally, monoseptated conidia were observed (Fig. 2). This fungal group was identified as a Neofusicoccum sp.

The provisional identification of $N$. arbuti, N. australe, and N. parvum based on morphological characteristics was confirmed using molecular analyses. ITS sequences of Neofusicoccum spp. from blueberry from Chile (Table 1) were aligned with extype GenBank ITS sequences of

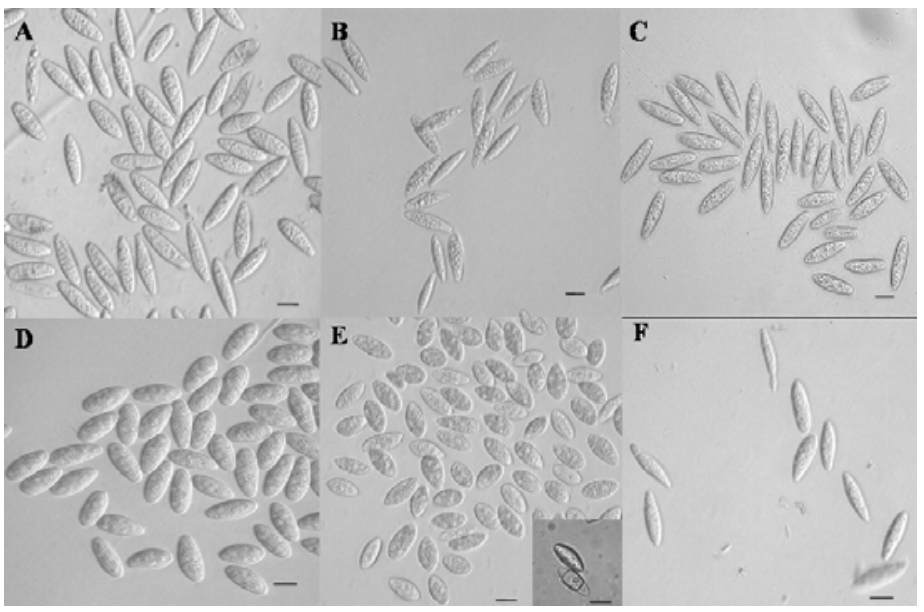

Fig. 2. Conidia of Neofusicoccum spp. obtained from blueberry in Chile. A-C, Conidia variability of Neofusicoccum arbuti; D, N. australe; E, N. parvum showing young, nonseptate fusiform conidia and a detail of old biseptate and fusiform conidia; F, Neofusicoccum sp. Bars $=10 \mu \mathrm{m}$.

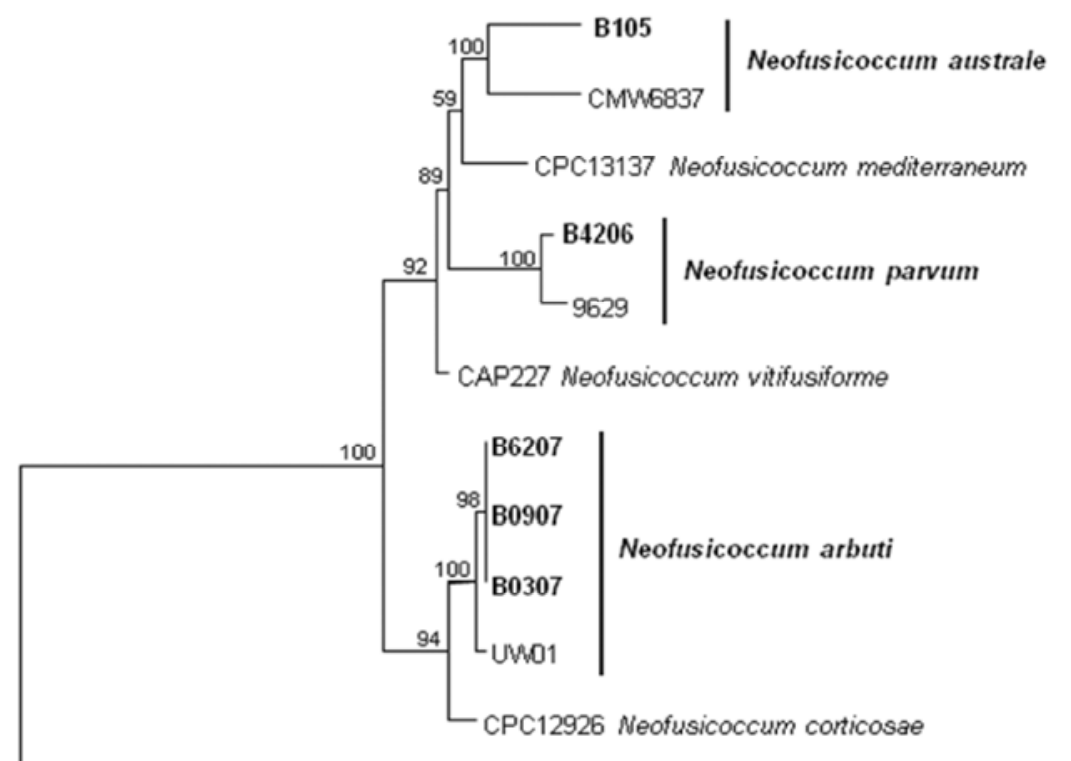

CMMBO00 Botryosphaeria dothidea

Fig. 3. One of 26 equally most parsimonious trees with bootstrap values from the 5.8S ribosomal DNA gene and flanking internal transcribed spacer (ITS) 1 and ITS 2 regions of Neofusicoccum spp. and outgroup Botryosphaeria dothidea isolate CMW8000. Tree length $=66$, consistency index $=0.894$, retention index $=0.837$, rescaled consistency index $=0.748$, and homoplasy index $=0.106$. Isolates in bold represent Neofusicoccum isolates from blueberry from Chile. 
Neofusicoccum isolates from other hosts (Table 3). Of the 530 nucleotides analyzed, 21 were parsimony informative. Maximum parsimony analyses of the ITS region resulted in 26 most parsimonious trees, 1 of which is shown (Fig. 3). Neofusicoccum isolates from blueberry from Chile showed sequences nearly identical to the extype isolates from other hosts from GenBank. $N$. arbuti, N. australe, and N. parvum isolates from Chile fell into three different, well-defined clades supported with $100 \%$ bootstrap values (Fig. 3).

Effect of temperature on mycelial growth. The analysis of variance showed a significant effect $(P<0.001)$ of temperature on mycelial growth. All isolates of Neofusicoccum grew at a range of temperatures from 10 to $35^{\circ} \mathrm{C}$ but optimum mycelial radial growth was observed at $25^{\circ} \mathrm{C}$. Isolates of $N$. parvum grew slightly at $5^{\circ} \mathrm{C}$ but no mycelial growth was observed at $0^{\circ} \mathrm{C}$. $N$. arbuti and $N$. australe did not grow at $5^{\circ}$. None of the Neofusicoccum spp. grew at $40^{\circ} \mathrm{C}$. N. parvum exhibited the fastest mycelial growth at $30^{\circ} \mathrm{C}$ among all Neofusicoccum spp.

Significant differences $(P<0.001)$ in mycelial growth rate were obtained between isolates at $25^{\circ} \mathrm{C}$. Differences in mycelial growth between $N$. parvum $(85.0 \mathrm{~mm}$ per 48 h) and $N$. australe $(76.6 \mathrm{~mm}$ per $48 \mathrm{~h})$ were statistically significant (Fig. 4).

Pathogenicity tests. All Neofusicoccum spp. used in this study were pathogenic on apple and kiwifruit fruit when inoculated with mycelia. Pathogenicity of $N$. parvum on apple and kiwifruit fruit was also determined using conidial suspension. Postinoculation symptoms on apple and kiwifruit were characterized by the development of a soft and watery rot that eventually covered the entire fruit. Superficially, white mycelia and black pycnidia developed after 7 days. Neofusicoccum isolates

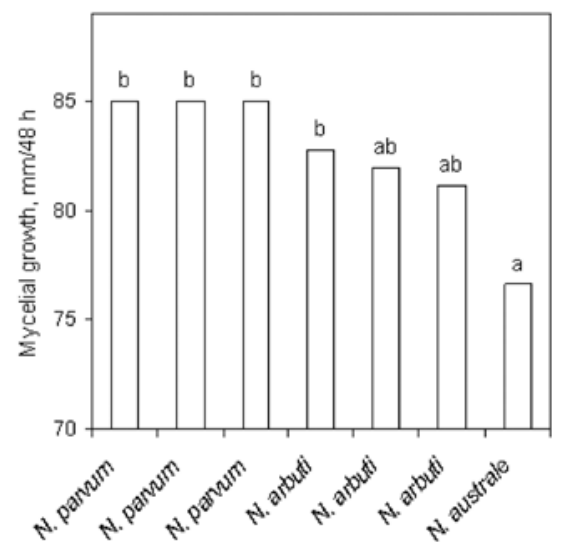

Fig. 4. Growth rate obtained for isolates of Neofusicoccum spp. after of 2 days of incubation at optimal temperature $\left(25^{\circ} \mathrm{C}\right)$. Isolates were Neofusicoccum australe (B1-05), $N$. arbuti (B09-07, B62-07, and B03-07), and N. parvum (B1-06, B4.2-06, and B02-07). Means followed by different letters are significantly different according to Tukey's test $(P=0.05)$. and inoculation method (wounded and unwounded fruit) had a significant effect ( $P=0.006$ and $P<0.001$, respectively) on the size of the rot lesions obtained. The interaction between the inoculation method and the isolates was significant $(P<$ $0.001)$. No symptoms were observed on noninoculated controls (Table 4).

All isolates were pathogenic on 2-yearold blueberry stems. Reddish-brown canker lesions from 13.3 to 95.5 and 11.3 to $70.7 \mathrm{~mm}$ in length were observed on blueberry cvs. Brigitta and O'Neal, respectively. Internally, a light-brown vascular necrosis was observed. Development of black pycnidia, which eventually liberated conidia in the form of whitish cirrus, was observed from infected stems (Fig. 1). Pathogenicity differences among isolates were significant $(P<0.05)$, with $N$. parvum being the most virulent species and $N$. arbuti the least virulent isolates (Table 4).

Both conidia and mycelia inoculation methods proved to be equally pathogenic on 2-year-old wounded blueberry cv. O'Neal stems when inoculated with $N$. parvum. However, the extent of necrotic discoloration obtained was considerably larger using conidial suspension than mycelial inoculations (Table 6).

In all pathogenicity tests, reisolations from necrotic stems were successful, and the same isolates with morphology identical to those used for inoculations were consistently recovered from diseased fruit and diseased blueberry stems.

Blueberry cultivar susceptibility. Based on analysis of variance, there was a significant effect between cultivars $(P<$ $0.001)$ and the length of the cankered lesions from the different Botryosphaeriaceae spp. on 2-year-old wounded stems when inoculated with mycelium. However, the interaction between cultivars and $\mathrm{NeO}$ fusicoccum spp. was not significant $(P=$ 0.057). Canker length was significantly different $(P<0.05)$ depending on the cultivar used. Among all cultivars tested, Elliot was shown to be the most susceptible; Brightwell, O'Neal, and Brigitta were moderately susceptible; and Misty, Bluecrop, and Duke were the least susceptible cultivars. With the exception of Brigitta, a similar trend was obtained when the same cultivars were inoculated with conidia of
N. parvum isolate B1-06, which proved to be highly virulent in previous experiments (Table 5).

Sensitivity to fungicides. Regardless of the isolate used, mycelia of $N$. parvum were highly sensitive to fludioxonil, resulting in complete mycelial growth inhibition at $1 \mu \mathrm{m} \mathrm{ml}^{-1}$. Isolates B1-06 and B4.2-06 exhibited 100 and $50 \%$ mycelial growth inhibition, respectively, with iprodione at 1 $\mu \mathrm{m} / \mathrm{ml}$. The relationship between percent mycelial growth inhibition and $\log$ of the fungicide concentration was explained linearly $\left(R^{2}>0.91\right)$, and the $\mathrm{EC}_{50}$ values for fludioxonil and iprodione fluctuated between 0.019 and $0.022 \mathrm{mg} \mathrm{ml}^{-1}$ and 0.021 and $0.2 \mathrm{mg} \mathrm{ml}^{-1}$, respectively.

\section{DISCUSSION}

This study represents the first attempt to determine the presence and diversity of Neofusicoccum fungi associated with canker and stem dieback symptoms in the major blueberry-producing areas of Chile. Three different Neofusicoccum spp. were identified to be associated with stem canker and dieback of blueberry in Chile, including $N$. arbuti, N. australe, and $N$. parvum. These fungi were isolated mostly during spring (November to March) on cvs. Aurora, Brigitta, Bluegold, Duke, Liberty, and Misty in a wide geographic zone that varied along a gradient from north to south from relatively dry to humid conditions (mean $<436$ to $<1,542 \mathrm{~mm}$ of annual rainfall) (26). However, it is interesting that $N$. arbuti was isolated only in southern Chile (Table 1), characterized by wet and cool weather conditions (26), while $N$. australe and $N$. parvum were isolated from plantings located in a warm and rather dry area of central Chile. Symptoms were reproduced after stem inoculations of blueberry. Reisolation of the causal agents from necrotic lesion development confirmed that these Botryosphaeriaceae spp. are pathogenic on blueberry. However, the relative importance of these species in the epidemiology of the stem canker and dieback of blueberry remain to be determined.

The symptoms obtained were similar to those described in blueberry-growing areas of United States caused by B. corticis and $B$. dothidea (23). Although $B$. dothidea was reported previously on blueberry in

Table 6. Pathogenicity on detached stems of O'Neal blueberry using mycelia and conidia of Neofusicoccum parvum after 25 days of incubation in a humid chamber at 20 to $25^{\circ} \mathrm{C}^{\mathrm{z}}$

\begin{tabular}{llcc}
\hline & & \multicolumn{2}{c}{ Blueberry stems inoculated with } \\
\cline { 3 - 4 } Species & Isolates & Mycelia $(\mathbf{m m})$ & Conidia $(\mathbf{m m})$ \\
\hline$N$. parvum & B02-07 & $20.3 \mathrm{c}$ & $55.0 \mathrm{~b}$ \\
$N$. parvum & B1-06 & $13.5 \mathrm{~b}$ & $75.0 \mathrm{~b}$ \\
$N$. parvum & B4.2-06 & $14.5 \mathrm{~b}$ & $48.7 \mathrm{c}$ \\
Noninoculated & $\ldots$ & $0.0 \mathrm{a}$ & $0.0 \mathrm{a}$ \\
\hline
\end{tabular}

${ }^{\mathrm{z}}$ Mycelia $=$ plug $5 \mathrm{~mm}$ in diameter and conidia $=15 \mu \mathrm{l}$ of a conidial suspension adjusted to $10^{6} \mathrm{co}-$ nidia/ml. Means followed by different letters in each column are significantly different according to Tukey's test $(P=0.05)$. 
Chile, this species was not confirmed in this study (11).

The colony characteristics, conidia morphology, and sequence analysis of the ITS1-5.8S-ITS2 of the nuclear rDNA confirmed the presence of $N$. arbuti, $N$. australe, and $N$. parvum. These identifications were based on anamorphic characteristics and were in agreement with previous descriptions $(10,15,20,38,40,47)$.

The shape, size, presence of septum, and pigmentation of conidia in combination with molecular data can be useful for identifying species of Botryosphaeriaceae isolated from blueberry, especially because the teleomorph stage was not found. However, conidial characters in Neofusicoccum spp. must be interpreted carefully because of their inherent variability. For instance, the presence of biseptated conidia with a dark-brown middle cell in cultures older than 30 days was a morphologically distinctive characteristic of $N$. parvum. However, the conidia were relatively larger than the conidia dimensions reported in other studies for $N$. parvum. It is possible that the differences in conidial size could be due to differences in the culture conditions used in this study. In a similar manner, a highly distinctive characteristic of $N$. australe was the slight yellow pigmentation observed in young colonies of APDA (29$31,45)$. However, the yellow pigmentation also characterizes young colonies of $N$. luteum (20). Therefore, DNA analysis appears to be necessary for the identification of Neofusicoccum spp.

To our knowledge, this is the first report of $N$. arbuti, $N$. australe, and $N$. parvum associated with diseased blueberry plants in Chile. Presence of B. ribis was reported previously in blueberry plantations located in the VIII, IX, and X administrative regions of Chile (16). The presence of $B$. dothidea and $B$. corticis was reported on blueberry in the United States (23), but $N$. arbuti, $N$. australe, and $N$. parvum have not been found in other blueberry-growing areas. Considering that blueberry was introduced primarily from the United States, it is interesting that $B$. corticis has not been found in Chile yet. It is possible that only clean plant material was introduced and plant quarantine measures were successful in avoiding its introduction.

Previous studies have associated Botryosphaeriaceae spp. as important pathogens causing wood and canker symptoms in other perennial crops in Chile and elsewhere $(1,2,4,12,19,24,30,46)$. Therefore, it is possible that more than one species of Botryosphaeriaceae can be associated with the stem canker of blueberry, as has been found in grapevines and other crops throughout the world $(36,45,47,48)$. Nevertheless, considerable differences in virulence were obtained among Botryosphaeriaceae spp. identified on blueberry in this study. $N$. parvum was the most aggressive species. It was interesting that a consider- able and consistent variability in virulence were obtained with $N$ parvum on stem inoculations of seven blueberry cultivars (Table 5). Further research is needed to verify these differences in virulence and the possible significance in the development of canker diseases.

Optimal temperature for mycelial growth was $25^{\circ} \mathrm{C}$. This temperature was lower than the optimal temperatures previously reported for $N$. australe and $N$. parvum $(21,35,47)$. This could suggest a possible adaptation of these species to the relatively cool conditions that characterize the central valley of Chile during the spring and summer months when most of the blueberry are planted.

The pathogenicity of these species in fruit other than blueberry suggests that they are not host specific and agrees with previous reports $(9,22,42,43)$. The necessity of a wound to initiate infection and the presence of cankers associated with pruning wounds suggest that pruning, frost damage, hail, mechanical injury, and other physical damages may favor the development of this disease under natural conditions, as has been suggested in other fruit crops $(7,36)$.

The susceptibility of blueberry cultivars to some Botryosphaeriaceae spp. has been reported in previous studies $(9,23,33$, 41,43). For instance, O'Neal has been shown to be resistant to stem canker caused by $B$. corticis but is susceptible to $B$. dothidea in the United States. In this study, Misty, Bluecrop, and Duke were the least susceptible cultivars to $N$. parvum in greenhouse experiments. However, field tests need to be performed in order to establish a final conclusion.

In Chile, blueberry plantations have considerably increased in recent years and are cultivated in very different soil and climatic conditions (3). This situation can partially explain the relatively rapid increase of these pathogens that may be disseminated from nurseries because evidence of the presence of Botryosphaeriaceae spp. in nursery plants was found in this study. Field diagnosis of the causal organism is difficult because symptoms caused by Botryosphaeriaceae spp. resemble those caused by Pestalotiopsis and Phomopsis spp., which sometimes coexist in the same plant (14). Pruning wounds can be an important avenue for penetration, as has been previously suggested on other fruit crops (30). Although fungicide treatments against this disease on blueberry are not currently recommended, the high sensitivity of $N$. parvum to fludioxonil and iprodione opens the possibility of developing a fungicide treatment to protect pruning wounds against these pathogens.

\section{ACKNOWLEDGMENTS}

We thank P. Bañados, Pontificia Universidad Católica de Chile, for her technical support and motivation during this work; Laboratorio de $\mathrm{Mi}$ cología Lo Aguirre, Servicio Agrícola y Ganadero, and Ministerio de Agricultura de Chile for their collaboration in performing the molecular analysis; Vital Berry Marketing S.A. for their financial support; and Hortifrut-viveros, Chile, and TrucaoAgrícola, S.A, for their collaboration during this work.

\section{LITERATURE CITED}

1. Ahumada, R. 2003. Pathogens in commercial Eucalyptus plantations in Chile, with special reference to Mycosphaerella and Botryosphaeria species. M.Sc. thesis, University of Pretoria, Pretoria, South Africa.

2. Auger, J., Esterio, M., Ricke, G., and Pérez, I. 2004. Black dead and basal canker of Vitis vinifera $\mathrm{cv}$. Red Globe caused by Botryosphaeria obtusa in Chile. Plant Dis. 88:1286.

3. Bañados, M. P. 2006. Blueberry production in South America. Acta Hortic. 715:165-172.

4. Besoain, X., Briceño, E. X., and Piontelli, E. 2000. Fusicoccum sp. as the cause of canker in almond trees and susceptibility of three cultivars. Fitopatología 35:176-182.

5. CABI, 2007. Index Fungorum. CABI Bioscience. Surrey, UK. www.indexfungorum.org (Accessed October 2007).

6. Caruso F. L., and Ramsdell, D. C., eds. 1995 Compendium of Blueberry and Cranberry Diseases. American Phytopathological Society Press, St. Paul, MN.

7. Cline, W. O. 1994. Infection of cold-injured blueberry stem by Botryosphaeria dothidea. Plant Dis. 78:1010.

8. Cooke, D. E. L., and Duncan, J. M. 1997. Phylogenetic analysis of Phytophthora species based on the ITS1 and ITS2 sequences of ribosomal DNA. Mycol. Res. 101:667-677.

9. Creswell, T. C., and Milholland, R. D. 1987. Responses of blueberry genotypes to infection by Botryosphaeria dothidea. Plant Dis. 71:710-713

10. Crous, P. W, Slippers, B., Wingfield, M. J., Rheeder, J., Marasas, W. F. O., Phillips, A. J. L., Alves, A., Burgess, T., Barber, P., and Groenewald, J. Z. 2006. Phylogenetic lineages in the Botryosphaeriaceae. Stud. Mycol. 55:235253.

11. Cuevas, G., and R. Acuña. 2004. Detección de enfermedades del follaje en arándano alto (Vaccinium corymbosum L.) en la VIII Región, Chile. Resúmenes XIII Congreso Sociedad Chilena de Fitopatología. Fitopatología 39:30.

12. Cunnington, J. H., Priest, M. J., Powney, R. A., and Cother, N. J. 2007. Diversity of Botryosphaeria species on horticultural plants in Victoria and New South Wales. Australas. Plant Pathol. 36:157-159.

13. Denman, S, Crous, P. W., Groenewald, J. Z. E., Slippers, B., Wingfield, B. D., and Wingfield, M. J. 2003. Circumscription of Botryosphaeria species associated with Proteaceae based on morphology and DNA sequence data. Mycologia 95:294-307.

14. Espinoza, J. G., Briceño, E. X., Keith, L. M., and Latorre, B. A. 2008. Canker and twig dieback of blueberry (Vaccinium spp.) caused by Pestalotiopsis spp. and Truncatella sp. in Chile. Plant Dis. 92:1407-1414.

15. Farr D. F., Elliott, M., Rossman A. Y., and Edmonds, R. L. 2005. Fusicoccum arbuti sp. nov. causing cankers on Pacific madrone in western North America with notes on Fusicoccum dimidiatum, the correct name for Scytalidium dimidiatum and Nattrassia mangiferae. Mycologia 97:730-741.

16. Guerrero, J. 2003. Cancro y tizón de tallo, causado por Botryosphaeria ribis y su anamorfo Fusicoccum sp. en arándano alto (Vaccinium corymbosum L.) y ojo de conejo (Vaccinium ashei Reade.) en la IX y X Región. XIII Congreso Sociedad Chilena de Fitopatología, Maitencillo, Chile. 
17. Jacobs, K. A., and Rehner, S. A. 1998. Comparison of cultural and morphological characters and ITS sequences in anamorphs of Botryosphaeria and related taxa. Mycologia 90:601-610.

18. Latorre B., Besoain, X., and Flores, V. 1986 Botryosphaeria canker of table grapes. (Abstr.) Phytopathology 76:1112.

19. Latorre, B. A., and Toledo, M. V. 1984. Occurrence and relative susceptibility of apple cultivars to Botryosphaeria canker in Chile. Plant Dis. 68:36-39.

20. Lazzizera, C., Frisullo, S., Alves A., and Phillips, A. J. L. 2008. Morphology, phylogeny and pathogenicity of Botryosphaeria and NeOfusicoccum species associated with drupe rot of olives in southern Italy. Plant Pathol. 57:948-956.

21. Michailides, T. J., and Morgan, D. P. 1992. Effects of temperature and wetness duration on infection of pistachio by Botryosphaeria dothidea and management of disease by reducing duration of irrigation. Phytopathology 82:1399-1406

22. Milholland, R. D. 1972. Histopathology and pathogenicity of Botryosphaeria dothidea on blueberry stems. Phytopathology 62:654-660.

23. Milholland R. D. 1995. Botryosphaeria stem blight. Pages 10-11 in: Compendium of Blueberry and Cranberry Diseases. F. L Caruso and D. C. Ramsdell, eds. American Phytopathological Society Press, St. Paul, MN

24. Mohali, S., Slippers, B., and Wingfield, M. J. 2007. Identification of Botryosphaeriaceae from Eucalyptus, Acacia and Pinus in Venezuela. Fungal Divers. 25:103-125.

25. NCBI. 2009. GenBank. National Center for Biotechnology Information, Bethesda, MD. www.ncbi.nlm.nih.gov. (Accessed March 2009).

26. Novoa, R., and Villaseca, S., eds. 1989. Mapa Agro Climático de Chile. Instituto de Investigaciones Agropecuarias, Santiago, Chile.

27. ODEPA. 2009. Estadísticas de la Agricultura Chilena. Oficina de Estudios y Políticas Agrarias, Ministerio de Agricultura, Gobierno de Chile. www.odepa.cl (Accessed March 2009).

28. Ogata, T., Sano, T., and Harada, Y. 2000. Botryosphaeria spp. isolated from apple and several deciduous fruit trees are divided into three groups based on the production of warts on twigs, size of conidia, and nucleotide sequences of nuclear ribosomal DNA ITS regions. Mycoscience 41:331-337.

29. Pennycook, S. R., and Samuels, G. J. 1985. Botryosphaeria and Fusicoccum species associated with ripe fruit rot of Actinidia deliciosa (kiwifruit) in New Zealand. Mycotaxon 24:445-458.

30. Phillips, A. J. L. 2002. Botryosphaeria species associated with diseases of grapevines in Portugal. Phytopathol. Mediterr. 41:3-18.

31. Phillips, A. J. L. 2007. The Botryospaheria Site. www.crem.fct.unl.pt/botryosphaeria_site/ (Accessed June 2007).

32. Phillips, A. J. L., Alves, A., Correia, A., and Luque, J. 2005. Two new species of Botryosphaeria with brown, 1-septate ascospores and Dothiorella anamorphs. Mycologia 97:513529.

33. Polashock, J. J., and Kramer, M. H. 2006. Resistance of blueberry cultivars to Botryosphaeria stem blight and Phomopsis twig blight. HortScience 41:1373-1520.

34. Ramos, L. J., Davenport, T. L., McMillan, R. T., Jr., and Lara, S. P. 1997. The resistance of mango (Mangifera indica) cultivars to tip dieback disease in Florida. Plant Dis. 81:509-514.

35. Sánchez M. E., Venegas, J., Romero, M. A., Phillips, A. J. L., and Trapero, A. 2003. Botryosphaeria and related taxa causing oak canker in southwestern Spain. Plant Dis. 87:15151521.

36. Savocchia, S., Steel, C. C., Stodart, B. J., and Somers, A. 2007. Pathogenicity of Botryosphaeria species isolated from declining grapevines in sub tropical regions of Eastern Australia. Vitis 46:27-32.

37. Slippers, B, Crous, P. W., Coutinho, T. A., Wingfield, B. D., and Wingfield, M. J. 2004. Multiple gene sequences delimit Botryosphaeria australis sp. nov. from $B$. lutea. Mycologia 96:1028-1039.

38. Slippers, B., Crous, P. W., Denman, S., Coutinho, T. A., Wingfield, B. D., and Wingfield, M. J. 2004. Combined multiple gene genealogies and phenotypic characters differentiate several species previously identified as Botryosphaeria dothidea. Mycologia 96:83101.

39. Slippers, B., Smith, W. A., Crous, P. W., Coutinho, T. A., Winfield, B. D., and Wingfield, M. J. 2007. Taxonomy, phylogeny and identification of Botryosphaeriaceae associated with pome and stone fruit trees in South Africa and other regions of the world. Plant Pathol. 56:128-139.

40. Slippers, B., and Wingfield, M. J. 2007. Botryosphaeriaceae as endophytes and laten pathogens of woody plants: diversity, ecology and impact. Fungal Biol. Rev. 21:90-106.

41. Smith, B. J. 1997. Detached stem assay to evaluate the severity of stem blight of rabbiteye blueberry (Vaccinium ashei). Acta Hortic. 446:457-464

42. Smith, B. J. 2006. Phytophthora root rot and Botryosphaeria stem blight: important disease of Southern highbush blueberries in the southern United States. Acta Hortic. 715:473-478

43. Stewart, P. J., Clark, J. R., and Fenn, P. 2005 Detached cane assay of resistance to Botryosphaeria cane canker (Botryospaheria do thidea) in eastern U.S. blackberry genotypes. Int. J. Fruit Sci. 5:57-64.

44. Sutton, B. C. 1980. The Coelomycetes, Fung Imperfecti with Pycnidia, Acervuli and Stromata. Commonwealth Mycological Institute, Kew, Surrey, England.

45. Úrbez-Torres, J. R., Gubler, W. D., and Luque, J. 2007. First report of Botryosphaeria iberica and $B$. viticola associated with grapevine decline in California. Plant Dis. 91:772-772.

46. Úrbez-Torres, J. R., Leavitt, G. M., Guerrero, J. C., Guevara, J., and Gubler, W. D. 2008 Identification and pathogenicity of Lasiodiplodia theobromae and Diplodia seriata, the causal agents of bot canker disease of grapevines in Mexico. Plant Dis. 92:519-529.

47. Úrbez-Torres, J. R., Leavitt, G. M., Voegel, T. M., and Gubler, W. D. 2006. Identification and distribution of Botryosphaeria spp. associated with grapevine cankers in California. Plant Dis. 90:1490-1503.

48. van Niekerk, J. M., Crous, P. W., Groenewald, J. Z., Fourie, P. H., and Halleen, F. 2004. DNA phylogeny, morphology and pathogenicity of Botryosphaeria species on grapevines. Mycologia 96:781-798.

49. White, T. J, Bruns, T., Lee, S., and Taylor, J. 1990. Amplification and direct sequencing of fungal ribosomal RNA genes for phylogenetics. Pages 315-322 in: PCR Protocols: a Guide to Methods and Applications. M. A. Innis, D. H. Gelfand, J. J. Snisky, and T. J. White, eds. Academic Press, San Diego, CA. 